\title{
Cell Division Inhibitor AK-01
}

National Cancer Institute

\section{Source}

National Cancer Institute. Cell Division Inhibitor AK-01. NCI Thesaurus. Code C148501.

An orally bioavailable agent that inhibits cell division, with potential antineoplastic activity. Upon administration, AK-01 inhibits cancer cell division, through an as of yet not elucidated mechanism of action (MoA). 